\title{
Pengaruh Penggunaan Google Classroom Terhadap Self-Directed Learning (SDL) Siswa Dalam Pembelajaran Bahasa Inggris
}

\author{
Rizal Akib ${ }^{1}$, Kris Uluelang ${ }^{2}$ \\ ${ }^{1}$ FKIP Universitas Muhammadiyah Sorong, ${ }^{2}$ FKIP Universitas Muhammadiyah Sorong \\ Email: ${ }^{1}$ rizalakib.ums@gmail.com, ${ }^{2}$ krisuluelang.ums@gmail.com
}

\begin{abstract}
Abstrak
Penelitian ini bertujuan untuk menguji penggunaan Google Classroom dalam meningkatkan Self-Directed Learning (SDL) mahasiswa dalam pembelajaran bahasa Inggris. Dengan menggunakan desain penelitian quasi-eksperimental, sebanyak 50 mahasiswa diberikan Pre-test PRO-SDLS sebelum diberikan pembelajaran bahasa Inggris yang didukung dengan penggunaan Google Classroom selama satu semester. Setelah itu, sampel penelitian ini kemudian diberikan post-test menggunakan instrument yang sama untuk mengetahui apakah ada perbedaan statistik antara hasil pre-test dan post-test. Hasilnya menunjukkan bahwa, ada perbedaan yang signifikan secara statistik pada SDL siswa antara pre-test dan post-test. Oleh karena itu, dapat disimpulkan bahwa menggunakan Google Classroom dapat membantu siswa untuk mengembangkan keterampilan SDL mereka dalam Pembelajaran Bahasa Inggris.
\end{abstract}

Kata kunci: Self-Directed Learning, Google Classroom, Learning Management System, LMS

\begin{abstract}
This study aims to examine the use of Google Classroom to enhance students'Self-Directed Learning (SDL) in English Learning. By using quasi experimental study, 50 students were pre-tested before given an English learning supported by the use of Google Classroom during a semester. Following the treatment, the students then post-tested using PRO-SDLS instrument in order to find out whether there was statistically differences between result of pre-test and post-test. The result shows that, there was statistically significant differences in the students' SDL between the pre-test and the post-test. Therefore, it can be concluded that using Google Classroom can helped students to develop their SDL skill in English Learning.
\end{abstract}

Keywords: Self-Directed Learning, Google Classroom, Learning Management System, LMS

\section{PENDAHULUAN}

Tujuan pendidikan pada saat ini tidak lepas dari tuntutan perkembangan teknologi sebagai kompetensi yang semestinya dimiliki baik guru maupun siswa. Teknologi internet misalnya, dewasa ini telah banyak mewarnai setiap sisi pendidikan kita, baik dari sisi pengajaran, pembelajaran, guru, siswa dan orang tua. Beragam kemudahan dan manfaat yang ditawarkan teknologi informasi menjadi salah satu pertimbangan pemanfaatan teknolgi dalam pengajaran dan pembelajaran. Penggunaan dan pemanfaatan teknologi juga telah banyak menjadi objek penelitian dalam rangka pengembangan pendidikan. Kemudahan yang dimaksud seperti memperoleh dan 
berbagi informasi, berdiskusi dalam kelompok, hingga interaksi antar guru dan siswa dalam satu media yang dapat diakses dimanapun dan kapan saja dengan berbantu teknologi computer dan internet.

Sebagai contoh, aplikasi sosial media pembelajaran atau learning management system (LMS) yang telah banyak digunakan saat ini mampu menghadirkan sebuah alternatif dimana guru dapat memperoleh dan berbagai bahan ajar, berinteraksi antar guru dan siswa hingga memberikan test secara online kepada siswanya. Edmodo misalnya, sebagai salah satu dari beberapa aplikasi sosial media yang dikhususkan untuk pembelajaran memIliki banyak fitur yang dapat dimanfaatkan oleh guru dan siswa baik didalam maupun diluar kelas melalui koneksi internet. Berbagai penelitian juga telah dilakukan dalam rangka menemukan bukti empiris manfaat serta dampak dari penggunaan aplikasi sosial media dalam pengajaran dan pembelajaran. Salah satu contoh dari penelitian yang telah dilakukan membuktikan bahwa dengan menggunakan Edmodo pada pembelajaran dapat membantu mengembangkan kemampuan Self-Directed Learning (SDL) siswa, yang mana secara sederhana self-directed learning dapat dipahami sebagai kemampuan siswa dalam berinisiatif mengidentifkasi apa saja yang siswa butuhkan dalam belajar dan atau tanpa bantuan orang lain serta menentukan sendiri target belajar yang akan dicapai (Khodary, 2017). Lebih lanjut, SDL juga merupakan salah satu model pembelajaran yang dibutuhkan untuk menjawab tantangan tujuan pendidikan dewasa ini yaitu model pembelajaran yang inovatif.

Beberapa penelitian dan kajian terkait penggunaan aplikasi sosial media dalam pengajaran dan pembelajaran diantaranya yang pernah dilakukan oleh (Dabbagh \& Kitsantas, 2012) dengan judul Personal Learning Environments, social media, and self-Direction learning: A natural formula for connecting formal and informal learning yang bertujuan untuk membuat konsep hubungan antara Lingkungan Pembelajaran Personal, Media Sosial dan Pembelajaran Mandiri, serta menyediakan tiga level kerangka dalam penggunaan media sosial untuk menciptakan Lingkungan Pembelajaran Personal yang mendukung pembelajaran mandiri siswa. Kajian ini Menyimpulkan bahwa mengajarkan siswa untuk menjadi peserta didik mandiri yang efektif dapat membantu mereka memperoleh keterampilan memanajemen pengetahuan personal dasar dan kompleks yang esensial untuk menciptakan, mengelola, dan mempertahankan Lingkungan Pembelajaran Personal dengan menggunakan beragam aplikasi sosial media yang tersedia. Kesimpulan ini tentunya dapat mendukung penelitian ini lebih lanjut sebagai dasar dalam menguji coba dan mendapatkan bukti 
empiris dalam menggunakan aplikasi media sosial lainnya yakni aplikasi Google Classroom dalam kaitannya terhadap kemampuan belajar Self-Directed siswa.

Selain itu, sebuah penelitian juga menunjukkan bahwa proses pembelajaran kolaboratif yang tertanam dalam platform pembelajaran media sosial yang disempurnakan sangat mendukung dan kondusif untuk penyelesaian masalah (problem solving) yang mengarahkan siswa pada keberhasilan pembelajaran bahasa asing yang dimaksud. Dengan temuan ini, peluang penggunaan media sosial dalam pembelajaran bahasa semakin terlihat jelas pada pengaruhnya terhadap kemampuan individu siswa dalam menganilisis kebutuhan belajarnya secara mandiri (SelfDirection Learning), yang mana kemadirian tersebut tentunya membutuhkan kemampuan Problem Solving didalamnya (Mondahl, Margrethe|Razmerita, 2014). Lebih lanjut, seiring berkembangnya pembelajaran berbasis online, dibutuhkan pembahasan yang berkesinambungan dalam memahami bagaimana strategi belajar Self-Directed siswa secara sukses dapat diraih didalam lingkungan pembelajaran berbasis online itu sendiri. (Broadbent \& Poon, 2015).

Melihat beberapa hasil peelitian diatas dan rekomendasi peneltian sebelumnya agar menguji penggunaan aplikasi yang berbeda untuk meningkatkan Self-Directed Learning (SDL) dalam pembelajaran Bahasa Inggris, Maka penelitian ini bertujuan untuk menguji penggunaan aplikasi Google Classroom untuk meningkatkan Self-Directed Learning (SDL) pada pembelajaran bahasa inggris.

\section{Self-Directed Learning}

Self-Directed Learning (SDL) adalah salah satu faktor yang memiliki keterkaitan pada kemandirian belajar. Sebagai bagian dari kemandirian belajar tentunya karakteristik SDL tidak lepas dari peran peserta didik dalam merencanakan kebutuhan dan target belajar mahasiswa secara mandiri. Hal yang sama seperti disebutkan oleh (Rachmawati, 2010) bahwa SDL adalah model pembelajaran yang mempertimbangkan gaya belajar mahasiswa dan memberikan otonomi pada mahasiswa dalam meyusun rencana pembelajaran, menentukan kegiatan pembelajaran, memonitoring, dan mengevaluasi hasil belajarnya secara mandiri. Melihat beberapa pengertian diatas, dapat disimpulkan bahwa Self-Directed adalah sebuah kemampuan afektif siswa yang dibutuhkan untuk mendukung siswa dalam melaksanakan kegiatan belajar. Yaitu kemampuan dalam membuat rencana belajar, menentukan model pembelajaran, mengontrol, dan mengevaluasi hasil belajar secara mandiri dalam proses yang teratur. 


\section{Google Classroom}

Sebagai salah satu bentuk teknologi web 2.0, aplikasi pembelajaran seperti Edmodo yang digunakan pada penelitian sebelumnya, memiliki kompetititor yang menawarkan fitur-fitur serupa pada Edmodo, sebut saja Moodle LMS, Schoology, Black Board dan Google Classroom. Aplikasiaplikasi ini seperti yang disebutkan adalah Social Networking Site atau Learning Management System (LMS) menawarkan sebuah sistem yang dapat digunakan oleh Guru, Siswa dan Orang tua dalam melakukan kegiatan Belajar, Mengajar dan Evaluasi. Sebagai contoh, Edmodo sebagai aplikasi yang banyak digunakan dengan alasan mudah digunakan, mendukung interaksi antara guru dan siswa, berdiskusi, berbagi materi berbentuk text, gambar, suara dan video serta dapat diakses melalui browser maupun aplikasi mobile (Al-Said, 2015). Jika diteliti lebih lanjut, fitur-fitur seperti yang disebutkan diatas adalah fitur mendasar yang hampir dimiliki semua aplikasi serupa Edmodo seperti Google Classroom.

Google Classroom sendiri adalah aplikasi yang dibangun oleh Google dan menawarkan sistem virtual berbasis aplikasi web dimana guru dapat memberikan dan memanajemen tugas yang diberikan kepada siswanya melalui web browser ataupun mobile app (Etherington, 2017). Penelitian kali ini akan menggunakan Google Classroom sebagai platform yang mendukung pembelajaran didalam maupun diluar kelas pada kelompok siswa yang telah dipilih.

\section{METODE}

Desain utama yang akan digunakan pada penelitian ini adalah quasi-experimental. Sebanyak 50 mahasiswa pada penelitian ini diberikan sebuah pre-test PRO-SDLS yang menguji skala orientasi personal mereka pada Self-Directed Learning sebelum diberikan treatment berupa pembelajaran Bahasa Inggris yang didukung dengan penggunaan aplikasi Google Classroom. Instrument PRO-SDLS adalah Personal Responsibility Orientation to Self-Direction in Learning Scale mampu mengukur skala kemampuan Self-Directed Learning partisipan dengan terdiri dari 25 item yang merupakan bagian dari 4 faktor SDL (Inisiatif, Kontrol, Self-Efficiay, dan Motivasi). Setiap item diukur dengan skala likert 5 point. PRO-SDLS adalah angket yang disusun berdasarkan teori-teori SDL yang dikembang oleh Brockett dan Hiemstra. Reliabilitas dan validitas instrument ini telah diuji pada banyak penelitian sebelumnya dan sangat cocok digunakan pada partisipan ditingkat perguruan tinggi (Khodary, 2017). Treatment juga dilakukan dengan cara membagikan 
materi pembelajaran secara online, diskusi online, kuis dan tugas-tugas yang dikerjakan secara online pada aplikasi Google Classroom selama pembelajaran satu semester. Setelah itu, mahasiswa diberikan post-test PRO-SDLS untuk kembali menguji skala orientasi personal pada Self-Direction Learning mahasiswa. Prosedur ini dilakukan untuk menjawab apakah penggunaan aplikasi Google Classroom dapat meningkatkan kemampuan Self-Directed Learning mahasiswa dalam pembelajaran Bahasa inggris.

\section{HASIL DAN PEMBAHASAN}

Setelah melaksanakan pengumpulan data pre-test dan post-test dilakukan uji statistik untuk menjawab hipotesis penelitian dibawah ini:

H0 : Tidak ada pengaruh penggunaan Google Classroom terhadap peningkatan kemampuan Self-Directed Learning Mahasiswa.

Ha : Ada pengaruh penggunaan Google Classroom terhadap peningkatan kemampuan Self-

Directed Learning Mahasiswa.

Perbandingan Hasil Pre-test dan Post-test

Berikut adalah grafik hasil yang diperoleh dari Pre-test dan Post-test PRO-SDLS berdasarkan empat faktor SDL (Inisiatif, Kontrol, Self-Efficiay, dan Motivasi) pada 50 mahasiswa.

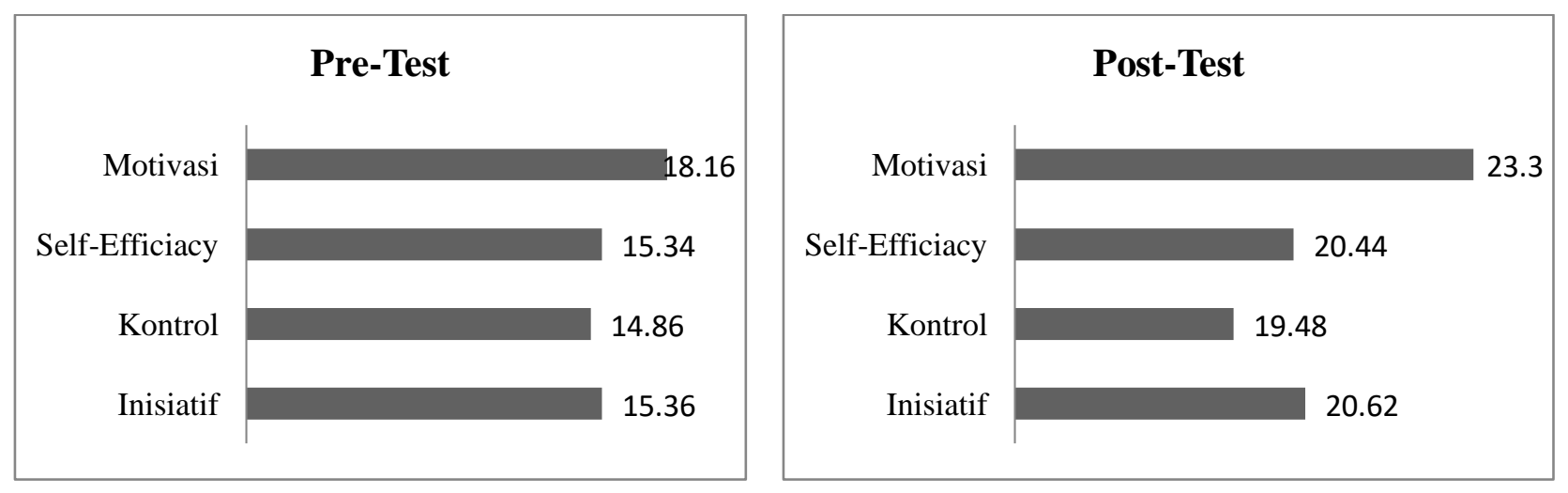

\section{Grafik 1. Perbandingan 4 faktor SDL pada Pre-test dan Post-test PRO-SDLS}

Terlihat pada grarik diatas bahwa ada peningkatan skor rata-rata yang cukup signifikan pada tiaptiap faktor SDL sebelum dan sesudah dilakukan treatment. 
Hasil Uji t Berpasangan

Tabel 1. Deskriptif Statistik Hasil Pre-Test dan Post-Test

\begin{tabular}{lllll}
\hline & Mean & N & Std. Deviation & $\begin{array}{l}\text { Std. Error } \\
\text { Mean }\end{array}$ \\
\hline Pre-Test & 63.72 & 50 & 4.463 & 0.631 \\
Post-Test & 83.84 & 50 & 5.092 & 0.720 \\
\hline
\end{tabular}

Berdasarkan tabel diatas diketahui bahwa nilai rata-rata pre-test sebesar 63.72 sedangkan nilai rata-rata untuk post-test adalah sebesar 83.84 dengan jumlah sampel sebanyak 50 orang mahasiswa. Berikutnya dilakukan uji t untuk melihat perbedaan statistik pada hasil pre-test dan post-test dalam upaya menjawab hipotesis diatas. Kemudian, didapatkan hasil uji seperti pada tabel dibawah ini.

Tabel 2. Hasil Uji t Berpasangan

\begin{tabular}{|c|c|c|c|c|c|c|c|c|}
\hline & \multicolumn{5}{|c|}{ Paired Difference } & \multirow[b]{5}{*}{$\mathrm{t}$} & \multirow[b]{5}{*}{ df } & \multirow{5}{*}{$\begin{array}{l}\text { Sig. }(2- \\
\text { tailed) }\end{array}$} \\
\hline & \multirow[b]{4}{*}{ Mean } & \multirow{4}{*}{$\begin{array}{l}\text { Std. } \\
\text { Deviation }\end{array}$} & \multirow{4}{*}{$\begin{array}{l}\text { Std. Error } \\
\text { Mean }\end{array}$} & \multirow{2}{*}{\multicolumn{2}{|c|}{$\begin{array}{l}95 \% \text { Confidence } \\
\text { Interval of the }\end{array}$}} & & & \\
\hline & & & & & & & & \\
\hline & & & & Differenc & & & & \\
\hline & & & & lower & Upper & & & \\
\hline $\begin{array}{l}\text { Pre_Test- } \\
\text { Post_Test }\end{array}$ & -20.120 & 6.400 & 0.905 & -21.939 & -18.301 & -22.228 & 49 & 0.0001 \\
\hline
\end{tabular}

Berdasarkan hasil uji diatas nilai t hitung 22,228 > nilai tabel t 2,231(df=49) yang berarti bahwa H0 ditolak dan Ha Diterima.

Hasil ini tentunya sejalan dengan hasil penelitian sebelumnya yang tujuan utamanya adalah menguji penggunaan aplikasi serupa namun pada sampel yang berbeda. Didapatkan hasil yang signifikan terhadap peningkatan kemampuan SDL mahasiswa. Hal ini selain dapat dilihat dari uji statistic diatas, dapat dipahami secara sederhana pada hasil pre-test dan post-test PRO-SDLS yang menunjukkan peningkatan yang cukup signifikan pada tiap-tiap aspek SDL. Sebagai contoh pada aspek inisiatif yang mendapatkan peningkatan nilai rata-rata yang cukup signifikan jika 
dibandingkan pada aspek lainnya, yakni dari 15.36 ke 20.62. Hal ini memperkuat sebuah teori yang menjelaskan bahwa SDL adalah model pembelajaran yang memberikan otonomi kepada mahasiswa dalam pembelajaran.

Fitur pada aplikasi Google Classroom yang memungkinkan aspek-aspek SDL dapat berkembang adalah, fitur seperti notifikasi, variasi materi pembelajaran (Video, Teks, dan Gambar). Fitur notifikasi memudahkan siswa untuk secara mandiri mengecek ketersediaan materi pembelajaran, kuis, dan tugas yang baru diberikan oleh guru. Sehingga dengan fitur notifikasi siswa diharuskan berinisiatif untuk melaksanakan kegiatan pembelajaran yang ada didalam aplikasi. Selain itu, beragam materi dan kegiatan pembelajaran juga turut mengembangakan motivasi siswa dalam belajar seperti berkomentar pada kolom komentar dengan pemberian materi berupa video.

\section{KESIMPULAN}

Kesimpulan dari penelitian ini adalah ada pengaruh signifikan pada peningkatan kemampuan Self-Directed Learning mahasiswa yang mendapatkan proses pembelajaran dengan menggunakan Google Classroom sebagai media pendukung dalam pembelajaran Bahasa Inggris. Kesimpulan ini didasarkan pada hasil uji statistik pre-test PRO-SDLS dan post-test PRO-SDLS mahasiswa. Maka, berdasarkan kesimpulan diatas peneliti menyarankan penggunaan Google Classroom pada proses pembelajaran lainnya. 


\section{REFERENSI}

Al-Said, K. M. 2015. Students' Perceptions of Edmodo and Mobile Learning and Their Real Barriers towards Them. Turkish Online Journal of Educational Technology - TOJET, 14(2), 167-180. Retrieved from https://eric.ed.gov/?id=EJ1057371

Broadbent, J., \& Poon, W. L. 2015. Self-regulated learning strategies \&amp; academic achievement in online higher education learning environments: A systematic review. The Internet and Higher Education, 27, 1-13. https://doi.org/10.1016/J.IHEDUC.2015.04.007

Dabbagh, N., \& Kitsantas, A. 2012. Personal Learning Environments, social media, and selfregulated learning: A natural formula for connecting formal and informal learning. The Internet and Higher Education, 15(1), 3-8. https://doi.org/10.1016/J.IHEDUC.2011.06.002

Etherington, D. 2017. Google Classroom now lets anyone school anyone else | TechCrunch. Retrieved November 20, 2019, from https://techcrunch.com/2017/04/27/google-classroomnow-lets-anyone-school-anyone-else/

Khodary, M. M. 2017. Edmodo Use to Develop Saudi EFL Students' Self-Directed Learning. English Language Teaching, 10(2), 123. https://doi.org/10.5539/elt.v10n2p123

Mondahl, Margrethe|Razmerita, L. 2014. Social Media, Collaboration and Social Learning--A Case-Study of Foreign Language Learning. Electronic Journal of E-Learning, 12(4), 339-352. Retrieved from https://eric.ed.gov/?id=EJ1035665

Rachmawati, D. O. 2010. Penerapan model self-directed learning untuk meningkatkan hasil belajar dan kemandirian belajar mahasiswa. In Jurnal Pendidikan Dan Pengajaran (Vol. 43). Retrieved from https://ejournal.undiksha.ac.id/index.php/JPP/article/viewFile/121/115 